\title{
Laboratory techniques in the investigation of chancroid, lymphogranuloma venereum and donovanosis
}

\author{
Eddy Van Dyck, Peter Piot
}

\section{Introduction}

Sexually transmitted diseases are not only highly prevalent in many populations of the developing world, but exhibit some special features. These include a high rate of complications and sequelae as a result of delayed or inadequate treatment, the important problem of antimicrobial resistance, particularly in Neisseria gonorrhoeae and Haemophilus ducreyi, and a high frequency of genital ulcer diseases. $^{12}$

We briefly review three causes of genital ulceration which are largely confined to the developing world, though all may be seen in Europe or North America as imported cases. In addition, outbreaks of chancroid have been reported from various western countries, and the disease has become even endemic in some populations of the USA. ${ }^{34}$ It therefore is not surprising that more research has been performed recently on chancroid than on donovanosis and lymphogranuloma venereum (LGV) which are rare conditions in the western world.

Some clinical and epidemiological features of tropical genital ulcers

Genital ulcerations are complex diseases and difficult to diagnose aetiologically on clinical grounds alone. Syphilis and genital herpes are common worldwide. The so called "tropical genital ulcer diseases" chancroid, lymphogranuloma venereum and donovanosis (granuloma inguinale) are infrequent in the industrialised world but cause major health problems in many developing countries. Interest in genital ulcerations has considerably increased following recognition that they enhance the risk of transmission of the human immunodeficiency virus (HIV) during sexual intercourse. ${ }^{5}$

Chancroid is caused by Haemophilus ducreyi. The disease starts with a painful papule at the site of infection resulting in a single or in multiple ulcers. Inguinal lymphadenopathy may be present in up to $50 \%$ of patients.

In patients with immunosuppression caused by HIV infection, extensive and persistent genital ulcers may be present without bubo development. Despite the fact that $H$ ducreyi isolates of these patients show a normal antimicrobial sensitivity in vitro, the ulcers heal less frequently after short course treatment with cotrimoxazole or erythromycin, and often fail to respond to longer antimicrobial courses.

LGV is caused by Chlamydia trachomatis.
Three serovars L1, L2 and L3 are responsible for the vast majority of cases but other $C$ trachomatis strains may also occasionally be isolated. ${ }^{67}$ LGV is a chronic disease with acute and late manifestations. A primary stage causing a small genital lesion is seen in a minority of patients. Most common is the secondary stage characterised by acute inguinal (and femoral) lymphadenitis with bubo formation. Late complications may occur in the anogenital area, such as ulcers, fistulas, strictures and elephantiasis.

Latent LGV may be reactivated in patients with HIV infection with development of multiple abcesses in the groins. The response to long courses of macrolides or tetracyclines is poor, and the destruction of inguinal lymphnodes often results in lymphoedema of the genitals, a chronic condition with persisting suppuration and pyoderma.

Donovanosis is a chronic infection of the genital region caused by Calymatobacterium granulomatis. The disease starts with a subcutaneous nodule at the site of infection. This nodule enlarges and erodes through the skin to reveal a red granulating ulcer. The disease may spread hematogenously resulting in cutaneous lesions at extragenital body sites.

\section{Laboratory techniques}

Chancroid The laboratory diagnosis of chancroid is based on the demonstration of the causative agent, $H$ ducreyi. Direct examination of ulcer material on Gram-stained smears may contribute to the diagnosis if typical small Gram negative bacilli grouped in chains or "schools of fish" are observed. However, these typical features are infrequently seen on smears from patients with culture-proven chancroid resulting in a sensitivity of much less than $50 \%{ }^{8-10}$ In addition most genital ulcers harbour a polymicrobial flora due to secondary contamination and the presence of Gram negative bacilli in a smear may be misleading and frequently results in a false positive diagnosis. ${ }^{11}$ Thus, the specificity of a Gram stain for the diagnosis of chancroid is also less than $50 \%$. Because of its low sensitivity and specificity, microscopic examination of a Gramstained smear is not recommended for the diagnosis of chancroid.

Accurate diagnosis of chancroid depends on the ability to culture $H$ ducreyi. Different isolation media have been used with varying success. For a review see table 1 . Nutritional requirements of $H$ ducreyi seem to be geographically defined and may partly explain the variation in detection rates of particular culture 
Table 1 Comparison of recovery rates on different culture media for isolation of Haemophilus ducreyi

\begin{tabular}{|c|c|c|c|}
\hline Study (reference) & Site & $\begin{array}{l}\text { Total number } \\
\text { of isolates }\end{array}$ & $\begin{array}{l}\text { Rate of isolation } \\
(\%)\end{array}$ \\
\hline Nsanze $1984^{12}$ & Nairobi & 163 & $\begin{array}{l}M H^{\star}: 75 \\
G^{12}: 88\end{array}$ \\
\hline Dylewski $1986^{13}$ & Nairobi & 75 & $\begin{aligned} M H^{\star} & : 71 \\
G^{\prime} & : 89\end{aligned}$ \\
\hline Kunimoto $1986^{14}$ & Nairobi & 27 & 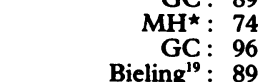 \\
\hline McDonald $1987^{15}$ & Nairobi & 57 & 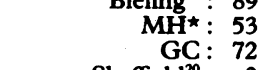 \\
\hline Taylor $1984^{16}$ & Bangkok & 45 & $\begin{array}{rr}\text { Sheffield }^{20}: & 2 \\
M^{\dagger} \dagger: & 93\end{array}$ \\
\hline Dieng Sarr $1991^{17}$ & Dakar & 46 & MH† $: 100$ \\
\hline Bogaerts $1989^{18}$ & Kigali & 38 & $\begin{array}{r}\text { MH! : } \\
\text { GC: }\end{array}$ \\
\hline Bogaerts 1991 (unpublished) & Kigali & 44 & $\begin{aligned} \mathrm{MH}+ & 82 \\
\mathrm{GC} & : 36\end{aligned}$ \\
\hline
\end{tabular}

$\mathrm{MH}^{\star}$ : Mueller Hinton enriched with chocolatized horse blood and Isovitalex.

$\mathrm{MH} \dagger$ : Mueller Hinton enriched with chocolatized horse blood, Isovitalex and $5 \%$ foetal calf serum.

MH : Mueller Hinton enriched with $1 \%$ hemoglobin, $1 \%$ VX supplement and $5 \%$ foetal calf serum. more than 1,000 strains of $H$ ducreyi isolated in eight countries on four continents between 1978 and 1987, and also shows the mechanisms of resistance for sulfonamides, trimethoprim, tetracycline, streptomycin, kanamycin, chloramphenicol and ampicillin.

The use of non-culture techniques for diagnosing chancroid is very limited. Recently described dot immunobinding and enzyme immunoassays for the detection of circulating serum antibody show somewhat limited sensitivity and IgG assays do not differentiate between active and past infection and are currently more useful for epidemiology rather than for diagnosis. ${ }^{34}{ }^{35}$ Geographical differences in the outer membrane profiles and antigenic composition of $H$ ducreyi as well as the qualitative and quantitative differences in the human immune response to chancroid are important obstacles to the development of diagnostic immunoassays.

Monoclonal antibodies produced against outer membrane proteins and against lipopolysaccharide react specifically with $H$ ducreyi by using an immunofluorescence technique ${ }^{36}$ (and E. Roggen, unpublished). The performance of a monoclonal immunofluorescence assay directly on clinical specimens has proven to be competitive with culture in sensitivity but to have a specificity of $60 \%$ only. ${ }^{36}$

DNA probes for the diagnosis of $H$ ducreyi directly in clinical specimens have not been evaluated yet and the probes used for culture confirmation are radioactively labelled with ${ }^{32} \mathrm{P}$, which is a handicap for routine use..$^{23} 24$

Lymphogranuloma venereum The laboratory diagnosis of LGV may be based on positive chlamydial serology, isolation of $C$ trachomatis from the infected site, and histological identification of chlamydia in infected tissue. In the differential diagnosis between LGV and other possible conditions, syphilis and herpes should always be considered. In serology three types of techniques are used: the complement-fixation (CF) test, the single L-type immunofluorescence test and the micro-immunofluorescence test (micro-IF). In general, a fourfold rise of antibody in the course of suspected illness is diagnostic of active infection. However, seroconversion is demonstrated in only a minority of cases since most patients are seen by the physician after the acute stage. Moderate or high serum titres may also be caused by other $C$ trachomatis infections and may persist for many years. Single-point CF titres of $\geqslant 1: 64$ are seen in the majority of patients and are considered indicative for active LGV. ${ }^{37}$ Single L-type chlamydial fluorescence seems to be more sensitive than CF, but also broadly crossreacts with serovars of $C$ trachomatis and, possibly, $C$ pneumoniae, and thus shows the same inconvenience as CF. ${ }^{38}{ }^{39}$ The most accurate diagnostic serologic assay is the microIF test. During the active phase of LGV patients usually show high levels of $\operatorname{IgM}$ (> 1:32) and $\operatorname{IgG}(>1: 512)$ with the antigen type of the infecting strain and much lower crossreactivity with other $C$ trachomatis strains ${ }^{39} 40$. ampicillin, streptomycin, kanamycin, tetracycline and chloramphenicol. $H$ ducreyi has remained susceptible to erythromycin and third generation cephalosporins. Table 2 summarises the antimicrobial susceptibility of 
Table 2 Antimicrobial susceptibility of clinical isolates of $H$ ducreyi

\begin{tabular}{|c|c|c|c|}
\hline $\begin{array}{l}\text { Antimicrobial } \\
\text { Sulfonamides } \\
\text { Ampicillin }\end{array}$ & $\begin{array}{l}\mathrm{MIC} \text { range }(\mathrm{mg} / \mathrm{l})^{\star} \\
0 \cdot 25->128 \\
0.03->128\end{array}$ & $\begin{array}{l}\text { Mechanism of resistance } \\
\text { plasmid } \\
\text { plasmid }\end{array}$ & $\begin{array}{l}\text { Molecular mass } \\
4.9 \mathrm{MDa} \\
\text { 3.2 MDa; } 5.7 \mathrm{MDa} ; \\
7.0 \mathrm{MDa}\end{array}$ \\
\hline $\begin{array}{l}\text { Tetracycline } \\
\text { Kanamycin } \\
\text { Chloramphenicol } \\
\text { Trimethoprim } \\
\text { Erythromycin } \\
\text { Ciproflaxcin } \\
\text { Ceftriaxone }\end{array}$ & $\begin{array}{l}0 \cdot 125-128 \\
0 \cdot 5-128 \\
0 \cdot 25-16 \\
0 \cdot 125-32 \\
0 \cdot 0002-0.125 \\
0 \cdot 002-0 \cdot 125 \\
0 \cdot 001-0.06\end{array}$ & $\begin{array}{l}\text { plasmid } \\
\text { plasmid } \\
\text { plasmid } \\
\text { transposon on chromosome } \\
\text { none } \\
\text { none } \\
\text { none }\end{array}$ & $\begin{array}{l}30 \mathrm{MDa} ; 34 \mathrm{MDa} \\
3 \cdot 1 \mathrm{MDa} \\
34 \mathrm{MDa}\end{array}$ \\
\hline
\end{tabular}

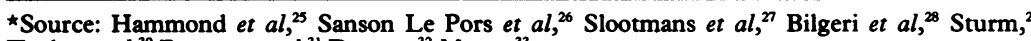

Taylor et al,,$^{30}$ Bowmer et al, ${ }^{31}$ Dangor, ${ }^{32}$ Morse. ${ }^{33}$

A major disadvantage of the micro-IF is that commercially ready to use reagents are not available and it therefore is primarily used in a few specialised reference laboratories. Cell culture is another method used for the diagnosis of LGV. $C$ trachomatis can be isolated from bubo pus, genital ulcer and rectal tissue on cycloheximide treated McCoy cells or DEAE treated Hela 229 cells, but the recovery rate seems to be lower than $50 \% .^{40}$ Material from the genital ulcer may be inoculated directly into cell tissue culture but bubo pus and tissues have to be homogenized in tissue culture medium to obtain a $10-20 \%(\mathrm{~W} / \mathrm{V})$ suspension, and $10^{-11}$ and $10^{-2}$ dilutions are inoculated into tissue culture. This is necessary to reduce a toxic effect of the pus on the culture cells.

Donovanosis The causative agent Calymatobacterium granulomatis appears in vacuoles in the cytoplasma of large histiocytes and occasionally in plasma cells and polymorphonuclear leukocytes. The intracellular organisms are called Donovan bodies and have a prominent clear capsule when mature. Culture of the bacterium in the chicken embryonic yolk sac has been reported, but is unsuccessful on artificial culture media. ${ }^{4142}$

The clinical manifestation is highly suggestive of granuloma inguinale and may be confirmed by Giemsa's, Leishman's or Wright's stain of a smear prepared from the lesion. A piece of clean granulation tissue is removed with a thin scalpel and crushed and spread on a slide and the impression obtained is air dried and stained. Deep coloured ovoid bacteria with or without capsule and with a closed safety-pin appearance are typical. Recently, a simple and more rapid diagnostic method has been described using a cotton swab for specimen collection and a one minute rapid differentiation staining technique, using eosin and thiazine dye solutions. As compared with a classic stain, no discrepant results were obtained. ${ }^{43}$

Donovanosis is likely to be confused with a number of diseases affecting the genital region. Perianal lesions may simulate condylomata lata. Dark field microscopy and serology may exclude syphilis. Appropriate culture may help differentiate chancroid. Other diseases which should be excluded are tuberculosis, amoebiasis, schistosomiasis and carcinoma. Histological aspects of a biopsy specimen may be helpful: an ulcer with a mixed inflammatory infiltrate of plasma cells, neutrophils and histiocytes, with a conspicuous absence of lym- phocytes suggests granuloma inguinale, and the use of Warthin-Starry silver impregnation stain demonstrating characteristic intracellular organisms (Donovan bodies) is diagnostic. ${ }^{44}$

1 Meheus A, De Schrijver A. Sexually transmitted diseases in the Third World. In: Harris JRW, Forster SM eds. Recent Advances in Sexually Transmitted Diseases and AIDS 4, 1991:201-17. Edinburgh: Churchill Livingstone.

2 Goeman J, Meheus A, Piot P. Epidémiologie des maladies sexuellement transmissibles dans les pays en développement à l'époque du SIDA. Ann Soc Belge Med Trop 1991;71:81-113.

3 Blackmore CA, Limpakarujarat K, Rigau-Perez JG, Albritton WL, Greenwood JR. An outbreak of chancroid in Orange County, California: descriptive epidemiology and disease control measures. $J$ Infect Dis 1985;151:840-44.

4 Schmid GP, Sanders LL, Blount JH, Alexander ER. Chancroid in the United States. Reestablishment of an old Chancroid in the United States. Ree

5 Piot $\mathrm{P}$, Laga $M$. Genital ulcers, other sexually transmitted diseases, and the sexual transmission of HIV. BMJ 1989;298:623-4.

6 Schachter J, Meyer KF. Lymphogranuloma venereum. Characterization of some recently isolated strains. $J$ Bacteriol 1969;99:636-8.

7 Piot P, Ballard RC, Fehler HG, Van Dyck E, Ursi JP, Meheus AZ. Isolation of Chlamydia trachomatis from genital ulcerations in Southern Africa. In: Mardh PA, Holmes KK, Oriel JD, Piot P, Schachter J eds. Chlamydial Infections 1982:115-8. Amsterdam: Elsevier Biomedical Press.

8 Choudhary BP, Kumari S, Bhati R, Agarwal DS. Bacteriological study of chancroid. Ind J Med Res 1982; teriological

9 Coovadia YM, Kharsany A, Hoosen A. The microbial aetiology of genital ulcers in black men in Durban, South Africa. Genitourin Med 1985;61:266-9.

10 Sturm AW, Stolting GJ, Cormane RH, Zanen HC. Clinical and microbiological evaluation of 46 episodes of genital ulceration. Genitourin Med 1987;63:98-101.

11 Chapel TA, Brown WJ, Jeffris C, Stewart JA. The microbia flora of penile ulcerations. J Infect Dis 1979;137:50-6.

12 Nsanze H, Plummer FA, Maggwa ABN, Maitha G, Dylewski J, Piot P, Ronald AR. Comparison of media for the primary isolation of Haemophilus ducreyi. Sex Transm Dis 1984;11:6-9.

13 Dylewski J, Nsanze H, Maitha G, Ronald A. Laboratory diagnosis of Haemophilus ducreyi: Sensitivity of culture media. Diagn Microbiol Infect Dis 1986;4:241-5.

14 Kunimoto DY, Slaney L, Koss J, et al. Field testing of modified Bieling media for the isolation of Haemophilus modified Bieling media for the isolation of Haemop

15 MacDonald K, Cameron D, Irungu G, et al. Comparison of Sheffield media with standard media in the isolation of Haemophilus ducreyi. Sex Transm Dis 1989;16:88-90.

16 Taylor DN, Dyangmani C, Suvongse C, et al. The role of Haemophilus ducreyi in penile ulcers in Bangkok, Thailand. Sex Transm Dis 1984;11:148-51.

17 Dieng Sarr A, Diouf G, Counillon E, et al. Diagnostic au laboratoire du chancre mou du bacille de Ducreyi Expérience du Sénégal. Seventh African Union against venereal Diseases and Treponematoses Regional Conference; Lusaka, Zambia, 1991. Abstract 142

18 Bogaerts J, Alvarez Ricart C, Van Dyck E, Piot P. The etiology of genital ulceration in Rwanda. Sex Transm Dis etiology of genita

19 Sturm AW, Zanen HC. Characteristics of Haemophilus ducreyi in culture. $J$ Clin Microbiol 1984;19:672-4.

20 Hafiz S, McEntegart MG, Kinghorn GR. Sheffield medium for the cultivation of Haemophilus ducreyi. Br J Venereal Dis 1984;60:196-8.

21 Sottnek FO, Biddle JW, Kraus SJ, Weaver RE, Stewart JA Isolation and identification of Haemophilus ducreyi in a clinical study. J Clin Microbiol 1980;12:170-4.

22 Lubwoma SW, Plummer FA, Ndinya-Achola J, Nsanze H, Namaara W. Isolation and identification of Haemophilus ducreyi in a clinical laboratory. J Med Microbiol 1986;22:175-8.

23 Parsons LM, Shayegani M, Waring AL, Bopp LH. DNA probes for the identification of Haemophilus ducreyi. J Clin probes for the identification
Microbiol 1989;27:1441-5.

24 Rossau $R$, Duhamel $M$, Jannes $G$, Decourt JL, Van Heuverswyn $H$. The development of specific rRNA derived oligonucleotide probes for Haemophilus ducreyi, derived oligonucleotide probes for Haemophilus ducreyi, the causative agent of chancroid. $J$ Gen Microbiol 1991;137:277-85.

25 Hammond GW, Lian CJ, Wilt JC, Ronald AR Antimicrobial susceptibility of Haemophilus ducreyi. Antimicrob Agents Chemother 1978;7:39-43.

26 Sanson Le Pors MJ, Casin IM, Thebault MC, Arlet G, Pero $Y$. In vitro activities of $U-63366$, a spectinomycin analog; roxithromycin (RU-28965), a new macrolide antibiotic and five quinolone derivates against Haemophilus ducreyi. Antimicrob Agents Chemother 1986;30:512-3.

27 Slootmans L, Vanden Berghe DA, Van Dyck E, Piot P Susceptibility of 40 Haemophilus ducreyi strains to 34 antimicrobial products. Antimicrob Agents Chemother 1983;24:564-7.

28 Bilgeri YR, Ballard RC, Duncan MD, Mauff AC, Koornhof HJ. Antimicrobial susceptibility of 103 strains of Haemo- 
philus ducreyi isolated in Johannesburg. Antimicrob Agents Chemother 1982;22:686-8.

29 Sturm AW. Comparison of antimicrobial susceptibility patterns of fifty-seven strains of Haemophilus ducreyi isolated in Amsterdam from 1978 to 1985 . J Antimicrob Chemother 1987;19:187-91.

30 Taylor DN, Echeverria P, Hanchalay S, Pitarangsi C, Slootmans L, Piot P. Antimicrobial susceptibility and characterization of outer membrane proteins of Haemophilus ducreyi isolated in Thailand. J Clin Microbiol $1985 ; 21: 442-4$.

31 Bowmer MI, Nsanze H, D'Costa LJ, Dylewski J, Fransen L, Piot $P$, Ronald AR. Single dose ceftriaxone for chancroid. Antimicrob Agents Chemother 1987;31:67-9.

32 Dangor Y, Miller SD, Exposto F da L, Koornhof HJ. Antimicrobial susceptibilities of Southern African Isolates of Haemophilus ducreyi. Antimicrob Agents Chemother 1988;32:1458-60.

33 Morse SA. Chancroid and Haemophilus ducreyi. Clin Microbiol Rev 1989;2:137-57.

34 Shalla WO, Sanders LL, Schmid GP, Tam MR, Morse SA. Use of dot immunobinding and immunofluorescence assays to investigate clinically suspected cases of chanassays to investigate clinically suspect
croid. J Infect Dis 1986;153:879-87.

35 Museyi K, Van Dyck E, Vervoort T, Taylor D, Hoge C, Piot $P$. Use of an enzyme immunoassay to detect serum IgG antibodies to Haemophilus ducreyi. J Infect Dis 1988; 157:1039-43.

36 Karim QN, Finn GY, Easmon CSF, et al. Rapid detection of Haemophilus ducreyi in clinical and experimental infec- tions using monoclonal antibody: a preliminary evaluation. Genitourin Med 1989;65:361-5.

37 Schachter J. Lymphogranuloma venereum and other nonocular Chlamydia trachomatis infections. In: Hobson D, Holmes KK eds. Nongonococcal Urethritis and Related Infections 1977:91-7. Washington: American Society for Microbiology.

38 Treharne JD, Forsey T. Chlamydial serology. Br Med Bull 1983;39:194-200.

39 Wang SP, Grayston JT. Micro immunofluorescence antibody responses in Chlamydia trachomatis infection, a review. In: Mardh PA, Holmes KK, Oriel JD, Piot P Schachter J eds. Chlamydial Infections 1982:301-16. Amsterdam: Elsevier Biomedical Press.

40 Perine PL, Osoba AO. Lymphogranuloma venereum. In Holmes KK, Mardh PA, Sparling PF, Wiesner PJ, Cate W, Lemon SM, Stamm WE eds. Sexually Transmitted Diseases 1990:195-204. New York: McGraw-Hill Book Co.

41 Anderson $\mathrm{K}$, De Monbreun WA, Goodpasture EW. An etiologic consideration of Donovania granulomatis cultivated from granuloma inguinale (three cases) in embryonic yolk. J Exp Med 1945;81:25-39.

42 Sehgal VN, Shyam Prasad AL. Donovanosis. Current Concepts. Int J Dermatol 1986;25:8-16.

43 O'Farrell N, Hoosen AA, Coetzee K, Van den Ende J. A rapid stain for the diagnosis of granuloma inguinale. Genitourin Med 1990;66:200-1.

44 Freinkel AL. Histological aspects of sexually transmitted genital lesions. Histopathology 1987;11:819-31. 